\title{
Hungary and the United States: A Comparison of Gifted Education
}

\begin{abstract}
There is a lot that can be learned about a country based on the programs and provisions it has for mathematically talented students. While it is difficult to identify a single U.S. "program" or "approach" for gifted education, in general the trend is to put mathematically talented students through the standard mathematics sequence, just starting at an earlier age. In Hungary, on the other hand, the focus is on enrichment over acceleration. This paper explores how some very different historical, cultural, and political forces have shaped these two countries' different approaches to educating mathematically talented students.
\end{abstract}

\section{Hungary and the United States: A Comparison of Gifted Education}

\section{Introduction}

In order to have some basis for comparing the educational systems in these two very different countries, it was necessary to choose a few dimensions of mathematics education on which to focus the comparison. The primary dimension chosen for this comparison is that of gifted education. There is a lot that can be learned about a country based on the programs and provisions it has for mathematically talented students; attitudes toward gifted education often stem from a country's political and cultural history. In general, some form of special education for talented students is something that these two countries have in common, when very few other dimensions are similar. It is also a relatively unique dimension - many countries have no provisions for educating gifted students, either rejecting the concept of giftedness or claiming that their overall educational system is of a high enough caliber to meet the needs of all students, gifted and average alike. This paper will explore how some very different historical, cultural, and political forces have shaped two different approaches to educating the mathematically talented.

Another reason that the dimension of gifted education was chosen for this comparison is because it is an area for which Hungary has already received international recognition. Hungarian students have traditionally scored very highly on International Mathematics Olympiads and other competitions. Additionally, the Hungarian system of specialized schools for mathematically talented students is believed to be the original model, which was later adopted by Russia and the United States. [Vogeli] Having already learned from the Hungarian model in the formation of some our top high schools for mathematically talented students, it stands to reason that an updated comparison of the two systems may help us identify even more innovations that could be implemented in the United States. Of course, one educational system cannot just be "cut and pasted" into another country. This is why this paper focuses on the additional dimensions of history, culture, and politics - to identify areas in which there is overlap and similar efforts may be well received in the other country, as well as things that are unique products of the circumstances in an individual country and unlikely to be replicable. 


\section{Hungary}

Hungary's history is a long and complicated one, involving frequent occupation by foreign powers, violent revolutions, and significant territory depletion following each of the World Wars. Through all of this political upheaval, however, the country managed to produce the highest per capita output of mathematicians and physicists for the first half of the $20^{\text {th }}$ century. [Vogeli] The superior numbers and quality of these mathematicians can be traced back to their excellent education in the secondary schools (gimnázium ) of Hungary, most notably in Budapest. The tradition of excellence in the Hungarian mathematics education system for secondary school students began at the end of the $19^{\text {th }}$ century under the supervision of then Minister of Education, Baron Loránd Eötvös. Son of the previous Minister of Education, and trained as a physicist, Eötvös founded the Mathematical and Physical Society, established a nation-wide mathematics exam competition to seek out and identify the most talented students, and opened a teacher training school - the Eötvös József Kollégium - to train bright lower- and middle-class young men as scientists and scholars as well as teachers. The Kollégium 's emphasis on what we would today call "content knowledge" in addition to "pedagogical knowledge" led to the development of a highly skilled cadre of mathematics and science teachers for Hungary's gimnazia. Eötvös believed that becoming a teacher was one of the single greatest contributions an individual could make to the growth and success of his country. [Wieschenberg] The placement of these exemplary teachers then translated down into the promotion of exceptional students. One of the most notable teachers of this time period was László Rátz, at the Evangelical (Lutheran) Gimnázium on Fasor Street; among his pupils were Eugene Wigner and John von Neumann. The schools with such exceptional teachers as Rátz became well known for their excellent teachers and the success of their former students, attracting even more bright teachers and students. These schools became centers of mathematics education, producing such notable mathematicians and physicists as Wigner, Pólya, Fejér, von Neumann, and more.

Over time, these schools formalized their impressive mathematics curriculum and became known as "special schools" for mathematics and physics. In 1968 for example, the special mathematics school curriculum involved 6 hours of mathematics per week for each of four years and 4 additional hours of "mathematical practice” per week (work in applied mathematics). In comparison, the general secondary schools required 4 or 5 hours of mathematics per week, and instead of mathematics practice students were involved in 2 to 5 hours of "practical exercises" - a key component of the socialist education system. [Buti] Practical experience often involved manual labor or factory training for students to help them become productive members of the socialist economy. The strong emphasis on work experience as a part of public schooling was a common tenet of socialist ideology - it was something of a backlash against the previous hierarchical class structure in which advanced education was the realm of the aristocracy and inaccessible for the working class. It is interesting to note that of all special schools (including those focused on performing and visual arts, physics and natural sciences, and foreign languages) mathematics special school students were the only ones exempt from the "practical experience” requirements. [Buti] Perhaps this anomaly stems from the fact that the mathematics schools had already been in existence for decades, or that their original format was protected by the demonstrated success of the earlier noteworthy mathematicians who had been graduates during the early part of the $20^{\text {th }}$ century. 
An additional difference between the mathematics special schools and the other special schools was their entrance requirements. Only the mathematics schools had special entrance exams. [Buti] These exams may have been related to another tradition in Hungarian mathematics education originating with Baron Loránd Eötvös - national mathematics competitions. The Mathematical and Physical Society founded in 1894 initiated an exam for secondary school students, later named the Eötvös Prize. The exam did not cover mathematics content beyond that taught in secondary school, but rather posed extraordinarily challenging problems within the topics of school mathematics. As Tibor Radó remarked, "the exam was not for the good student. It was for the future creative mathematician.” [Wieschenberg] Winners of the competition form a "who's who" list of Hungarian mathematicians, including physics Nobel Prize winners. The competition therefore became known as an identifier of young talent, and so winners of the competition are granted automatic admission to university and are frequently mentored by earlier winners - who are now prominent mathematicians and professors.

The special mathematics schools in Hungary are still in existence today, located mostly in Budapest with some in the other major urban centers (Szeged, Debrecen, Pécs, etc). The exact number of schools and the fate of specific notable schools from the $20^{\text {th }}$ century have not been fully determined at this time. Fazekas Gimnázium , one of the leading schools in Budapest, is still operational and hosted the Teachers College Mathematics Department Study Tour to Budapest \& Prague in March of 2008. From visiting Fazekas, we learned that most teachers still employ an open dialogue approach toward mathematics in the classroom, with an emphasis on problem solving, creative solutions, seeing a topic or problem from multiple angles, and highlighting the connections between a wide variety of subjects within mathematics.

In addition to the special schools, there are a number of extracurricular venues for mathematically talented students to pursue their interests. These include study circles, summer workshops, Saturday classes, and participation in national and international mathematics competitions. Many of these offerings have been in existence since the beginning of the $20^{\text {th }}$ century, when the Mathematical and Physical Society founded the first journal of mathematics for secondary school students. The journal, KöMaL, is still in operation today, and provides readers with challenging problems each month. Students then submit their responses to the journal by mail and scores are tallied throughout the year. At the end of the year, the top responders receive a monetary prize as well as being published in the journal, and are frequently accorded automatic admission to university. Continuing the traditional emphasis on problem solving and creativity, the journal publishes the most creative and elegant solutions that have been submitted.

Many other extracurricular offerings are currently being provided by the new Centre for Gifted in Budapest. Founded in 1990, the centre aims to reach a wider audience of students than just those who reside in Budapest, and who may not all qualify for admission into the special schools but are still gifted in mathematics and seek additional challenges beyond what their schools provide. Much of the Centre's work involves providing enrichment programs for gifted students at a young age, with the goal of fostering and maintaining their early interest in science or mathematics, until they are old enough to pursue programs such as the special schools. The Centre does not recruit or identify talented students; rather, it provides a service for parents looking for more 
options to impart a more appropriate education for their child. [Herskovits] It is interesting that it is only in 1990 that parental involvement and choice seems to have become a driving force in the educational system for gifted students; perhaps before that time it was not considered appropriate for parents to question the services the school system provided.

\section{United States}

In a democratic political system such as in the United States, there are alternating pushes toward meritocracy and egalitarianism. On the one hand, we pride ourselves on being a "land of opportunity", where anyone can "pull themselves up by their bootstraps" and achieve success regardless of race, gender, or socio-economic status. This point of view rewards those with exceptional talent, and seeks to provide them with opportunities to maximize that talent. On the other hand, the country was founded on the fundamental principle that "all men are created equal" and our origins are as a nation that overthrew a system of government with a ruling aristocratic class. We have been wary of allowing a new elite class to develop. [Gallagher] In terms of gifted education, this means that "when society seems to be threatened - as it was in World War II and the Sputnik era, or as it is now by pollution, limited energy, inflation, etc. - we lean towards the productive use of all talent. In more placid eras, such as the post-World War II decade, when there seemed to be little to worry and threaten us, we seek equality as a more appropriate goal." [Gallagher]

During these "placid” times Gallagher refers to, gifted programs are viewed as "undemocratic", elitist, and unfair allocations of resources. During times like the Sputnik era, on the other hand, there has been a marked increase in public and governmental support for gifted education, specifically in science and mathematics. At that point in time, mathematically talented students became a national resource and their appropriate and successful education became a national responsibility.

At the beginning of the $20^{\text {th }}$ century, psychologist Lewis Terman designed the Stanford-Binet Individual test of Intelligence (the most common form of IQ test), and used this assessment tool to identify extraordinarily gifted individuals for an unprecedented longitudinal study. The Stanford-Binet test became the standard for measuring an individual's talent or "giftedness". In the Marland Report in 1972, American conceptions of giftedness expanded and was defined as follows: "Children capable of high performance include those with demonstrated achievement and/or potential ability in any of the following areas:

1. General intellectual ability

2. Specific academic aptitude

3. Creative or productive thinking

4. Leadership ability

5. Visual and performing arts

6. Psychomotor ability” [Marland, as quoted in Gallager]

Currently, the emphasis on educational equity has led to increased criticisms of gifted programs. Given how many groups are underrepresented in these programs, it seems as though the traditional identification methods of IQ tests or standardized test results are 
not fully accurate measures of talent. We have also shifted to a much broader conception of giftedness. Presently, in addition to the classic "academic intelligence", educators are being asked to consider the multiple intelligences students can possess - ranging from creative and emotional intelligence to spatial and physical intelligence. The expansion of the conception of giftedness is frequently driven by parent groups or educators who feel that gifted programs are unfair if not everyone qualifies to attend; yet another factor leading to the lack of consistency in school districts' approaches to gifted education. [Yecke]

How is all of this being translated into programs for mathematically talented students? The very broad and multi-faceted definition of giftedness has made it that much more difficult to selectively identify gifted students. Part of the problem is that because there has been so much debate as to whether to provide a specialized educational program for these students, much less attention was paid to how best to provide a specialized educational program. There are special classes or pullout programs, mentoring programs with outside career professionals, Saturday workshops, summer camps, etc. [Gallagher]. Many gifted programs for young students have been criticized for being little more than "fun-and-games" activities with no real academic content. And while aptitude in mathematics is often used as an early indicator for general giftedness, most U.S. programs do not separate students into specific subject-field tracks until high school at the earliest, and usually specialization does not really occur until college. Therefore, the majority of programs designed specifically to foster mathematical talent are at the secondary school level.

Some states have adopted the Hungarian special schools model in the form of state-wide residential magnet schools, such as the Illinois Math and Science Academy (IMSA) and the North Carolina School for Science and Mathematics (NCSSM). Other magnet schools are regional, often in urban centers where the population can support a large enough applicant pool. These schools were frequently founded in partnership with nearby universities, and some are held on university campuses. Others were initiated in collaboration with research or business centers, so that students have access to advanced research equipment and mentorship opportunities during high school. Because of the autonomy of states and school districts, and the increased autonomy many of these magnet schools are accorded through their status as "governor's schools” or some similar designation, the structure and requirements of the curriculum vary greatly among math and science magnet schools and between the magnet schools and other schools in their state. For example, the Thomas Jefferson High School for Science and Technology in Alexandria, VA (recently rated the \#1 high school in the nation by U.S. News and World Report) emphasizes Advanced Placement courses, through which students are essentially covering college-level material while in high school. For mathematics, this means that all students are required to take Calculus in order to graduate, and many proceed on to Linear Algebra, Multivariable Calculus, or even Differential Equations as juniors and seniors. The Illinois Math and Science Academy, on the other hand, did not want to be tied to the Advanced Placement course requirements and so provides a wider offering of mathematics courses with an emphasis on enrichment electives such as Number Theory or Problem Solving. [IMSA] Again, these are just two examples of different approaches to mathematics education for exceptionally talented students in the United States. The scope of this paper is not large enough to cover the enormous variety of programs and 
offerings in a single large city or state, much less the entire country. This lack of consistency in gifted education is one of the main differences between the U.S. and Hungarian systems. Further differences and similarities are discussed in the following section.

\section{Comparison}

\section{Program Structure}

While it is difficult to identify a single U.S. "program” or "approach" for gifted education, as discussed above, in general for mathematically talented students the trend is to put them through the standard mathematics sequence, just starting at an earlier age. Taking Algebra I in $7^{\text {th }}$ grade, for example, allows for completion of Advanced Placement Calculus BC in $11^{\text {th }}$ grade, and magnet schools such as TJHSST and Stuyvesant often have offerings beyond calculus for the $12^{\text {th }}$ grade (or younger!) students. In Hungary, on the other hand, the focus is emphatically on enrichment over acceleration. In the general education system mathematics is not separated into distinct, sequential courses - it is all considered one topic (with the possible exception of geometry that historically was taught as a drawing and art-related skill and is frequently listed separately from mathematics on curriculum hours-allotment charts). Likewise in the special schools, students are not stepping through a sequence of mathematics courses faster than average, rather, they are going more in depth and forming more complex connections between topics. [Pataki]

\section{Cultural Forces}

In both cases, the need for special education of mathematically talented students has been championed mainly by individual educators or mathematicians. In the United States, these individual efforts were frequently short-lived and unable to bring about lasting change in an area larger than a single school or district. In Hungary, however, perhaps due to the country's much smaller size, or perhaps due to the much higher amount of influence wielded by the individual who made it his business to care (Baron Loránd Eötvös), it seems as though the efforts of an individual had extraordinarily longlasting results. In fact, the continued success of the Hungarian mathematical education programs for gifted students has been driven by the continued involvement of the mathematics academic community. Prominent mathematicians give lectures for secondary school students, and have an informal mentoring system established to help the brightest students succeed in their university studies, whether in Hungary or abroad. This environment of nurturing developing talent continues the tradition of excellence.

In the United States, on the other hand, there seems to be a "line drawn in the sand" between the academic mathematicians and educators. There is the pervasive cultural stereotype that "those who can't do, teach", and Ph.D. mathematicians frequently consider K-12 education a waste of their talents. In contrast, in Hungary one of the most important things a mathematician can do with his or her talent is to share it with the next generation of Hungarian mathematicians. It is all the more remarkable that mathematicians view teaching as such a laudable profession given that Hungarian teachers are some of the lowest paid government employees and have an extremely low socio-economic status compared to other professions. [Vári] 


\section{Political Forces}

It is surprising that a socialist country operating under Marxist-Leninist ideology would have established any kind of separate groupings for any kind of student. On the surface, it seems that socialism would call for equal education for all students - no special provisions - no developing of an "intelligentsia" that is separate from the working class. However, as Swetz points out in his book Socialist Mathematics Education it was actually a very common phenomenon. Most socialist countries appear to have embraced the concept of giftedness as a national resource; talented individuals should be encouraged in their interests and given a strong educational foundation so that they can go on to use their talents for the good of their country. [Swetz] As explained by a Ministry of Education official in 1968, "It is an important social and personal interest to educate pupils who have a special inclination to a subject or a branch of sciences. It is an important task of the socialist pedagogy and school policy to educate highly talented pupils. This task is served by the specialized classes." [Buti, 151] This mentality echoes the U.S. educational system's response to Sputnik and the need for qualified engineers and scientists in order for the U.S. to be competitive in the space race during the Cold War. It seems that since the end of the Cold War, much of that drive for improved mathematics and science education has fizzled out. There is less prestige associated with mathematics for students, and no overwhelming international conflict to spark public support for increased attention or funding for mathematics education initiatives.

In addition to the historical differences in political ideology, there is also a significant difference in government structure between the two countries. Hungary's education system is run by the national government through the Ministry of Education. The United States education system is much more decentralized, with the majority of control resting in the hands of state, county, town, or school district authorities. This makes it difficult to compare the U.S. to other countries because there is no single curriculum or number of hours spent on mathematics or national textbook or governmentmandated pedagogy. Rather, there are a wide variety of approaches, especially in the case of gifted education. The decentralized nature of the U.S. educational system is one of the topics that makes it so difficult to design and implement large-scale reforms. With so many interest groups vying for control of educational decisions and no central authority that can really mandate changes, it is not such a surprise that the field of gifted education in the U.S. has such a scattered history largely dependent on the persuasiveness and activism of individual educators.

And of course there is the factor of the country's size. When asked about how to transfer many of the highlights of Hungarian mathematics education for talented students to the United States, some educators have replied that it can't be done - the U.S. is just too big, too diverse, and that it would therefore be impossible to recreate the small, cohesive program that Hungary employs. [Pataki] However, it may be possible to introduce some of the Hungarian innovations on a smaller scale. This is especially likely since U.S. education is so decentralized - one school district or state may be able to reproduce an environment very much like that in Hungary, since they have local control over establishment of special schools, choice of curricula, etc. Changing teaching practices is a bigger endeavor and one that educational reformers have struggled with for decades. One can only hope that comparative studies such as this one, that highlight the success achieved by countries whose teachers utilize a creative problem-solving approach 
to mathematics, will be able to open the eyes of a few mathematics teachers, who can then expose their colleagues to the different approach, and so on. Change may come slowly, but it is possible!

\section{Works Cited}

Buti E. Public Education in the Hungarian People's Republic. Budapest, Hungary: Tankönyvkiadó; 1968.

Gallagher J. The Education of Gifted and Talented Students: A History and Prospectus. Washington: Council for Basic Education; c1979.

Herskovits M. Developing Programs for Science-Minded Children at the Age of 7-12. In Science Education: Talent Recruitment and Public Understanding. Proceedings of the NATO Advanced Research Workshop on Science Education, held April 19-21, 2002, in Budapest, Hungary. Amsterdam: IOS Press; 2003. pg. 44-52

Illinois Math and Science Academy (IMSA). Mathematics department website; course listings. http://staff.imsa.edu/math/curriculum/curr.html Accessed May 8, 2008.

Pataki J. personal communication. Teachers College Study Tour to Budapest \& Prague. March, 2008.

Swetz F. Socialist Mathematics Education. Southampton, Penn: Burgundy Press; 1978.

Vári P. Are We Similar in Math and Science? A Study of Grade 8 in Nine Central Eastern European Countries. Hungary: Országos Kozoktatási Intezet; c1997.

Vogeli B. Special Secondary Schools for the Mathematically and Scientifically Talented; an International Panorama. New York: Teacher’s College, Columbia University; 1997.

Wieschenberg A. Identification and Development of the Mathematically Talented - the Hungarian Experience. Ph.D. dissertation, Columbia University; 1984.

Yecke C. The War Against Excellence: The Rising Tide of Mediocrity in America's Middle Schools. Westport, CT: Praeger; 2003.

Dr. Julianna Connelly received her Ph.D. in Mathematics Education from Teachers College, Columbia University in 2010 and has accepted a position as Assistant Professor of Mathematics at Sacred Heart University in Fairfield, CT starting in September, 2010. She earned a B.S. in Mechanical Engineering from Olin College in 2006 and an M.A. in Mathematics Education from Teachers College in 2007. Her research interests include international comparative mathematics education, retention of female students in advanced mathematics, and education of gifted and talented students. Her teaching interests include inquiry-based learning, incorporation of historical sources in mathematics courses, and education of prospective K-12 teachers. Dr. Connelly conducted her dissertation research on the changes in the Hungarian education system for mathematically talented students over the past 20 years. 